\title{
GERMINAÇÃO IN VITRO DE EMBRIÕES ZIGÓTICOS DE MURMURU (Astrocaryum ulei)
}

\author{
In vitro germination of 'Murmuru' zygotic embryos (Astrocaryum ulei)
}

\author{
Jonny Everson Scherwinski Pereira', Tissiane Maria Silva Maciel$^{2}$, \\ Frederico Henrique da Silva Costa ${ }^{3}$, Maria Aparecida Alves Pereira ${ }^{2}$
}

\begin{abstract}
RESUMO
Com o presente trabalho objetivou-se avaliar a influência de concentrações de sacarose e a idade fisiológica da semente na germinação in vitro de embriões zigóticos de murmuru. Frutos em dois estágios de desenvolvimento coletados de plantas do campo tiveram os embriões excisados, desinfestados e inoculados em meio de cultura de MS com 75\% das concentrações de sais, suplementado com 2,5 g.L $\mathrm{L}^{-1}$ de ácido giberélico e diferentes concentrações de sacarose: 15,30 e 45 g.L. ${ }^{-1}$. Em sala de crescimento, o material foi mantido por 30 dias no escuro, sendo transferido em seguida para condições luminosas de $30 \mathrm{me} \cdot \mathrm{m}^{-2} \cdot \mathrm{s}^{-1}$, temperatura de $25 \pm 2^{\circ} \mathrm{C} \mathrm{e}$ fotoperíodo de 16 horas para completo desenvolvimento. $\mathrm{O}$ delineamento estatístico utilizado foi inteiramente casualizado em arranjo fatorial 2 x 3, com seis repetições e cinco embriões por parcela. Após 30 dias foi avaliada a porcentagem de germinação e altura das plântulas. Verificou-se que embriões provenientes de frutos imaturos apresentaram maior porcentagem de germinação, sendo a concentração de 30 g.L. $\mathrm{L}^{-1}$ de sacarose a que proporcionou os melhores resultados dentre as demais testadas. Embriões provenientes de frutos maduros apresentaram altura de plântulas significativamente maior aos imaturos e também para essa variável, a concentração de 30 g.L $\mathrm{L}^{-1}$ de sacarose foi a que proporcionou os melhores resultados.
\end{abstract}

Termos para indexação: Astrocaryum spp., palmeira, murumuru, embriogênese, carboidrato, cultura de tecidos.

\begin{abstract}
The work aimed to evaluate the influence of sucrose concentrations and seed physiologic age on the in vitro germination of murmuru zygotic embryos. Fruits collected from field plants in two development stages had the embryos excised, desinfected and inoculated onto MS medium with $75 \%$ salts, $2.5 \mathrm{~g} . \mathrm{L}^{-1}$ of giberelic acid and different sucrose concentrations: 15,30 and $45 \mathrm{~g} . \mathrm{L}^{-1}$. All cultures were kept for 30 days in the dark at $25 \pm 2^{\circ} \mathrm{C}$, being transferred afterwards to a growth chamber with $30 \mathrm{mmol}^{-2} \mathrm{~s}^{-1}$ of radiation and 16 hours photoperiod for complete development. The statistical design was a $2 \times 3$ factorial, with six repetitions and five embryos by experimental unit. After 30 days it was evaluated the germination percentage and plantlets height. It was verified that embryos from immature fruits presented higher germination percentage and the sucrose concentration of 30 g.L. $L^{-1}$ was the one that provided the best results among the others tested. Embryos from mature fruits gave rise to plantlets with average height significantly greater than that of plantlets from immature fruits and $30 \mathrm{~g} . \mathrm{L}^{-1}$ of sucrose was the concentration that provided the best results.
\end{abstract}

Index terms: Astrocaryum spp., palm, murumuru, embriogenesis, carbohydrate, tissue culture.

(Recebido para publicação em 26 de janeiro de 2005 e aprovado em 27 de junho de 2005)

\section{INTRODUÇÃO}

Nas últimas décadas, os produtos florestais nãomadeireiros da Região Amazônica têm sido revalorizados e sua utilização incrementada em virtude da valorização de uma vida de hábitos mais saudáveis e, conseqüentemente, pelo consumo de produtos naturais. Entre as espécies fornecedoras destes produtos, destaca-se a palmeira murmuru (Astrocaryum spp.) com grande potencial de uso na indústria de cosméticos, bem como na industrialização de margarinas (SOUSA et al., 2004).

O murmuru pode ser encontrado por toda Região Amazônica. No entanto, há poucas informações sobre a botânica, ecologia, biologia reprodutiva e comportamento silvicultural ou agronômico devido se tratar ainda de uma espécie silvestre. O que se sabe é que essa espécie apresenta um grande potencial econômico para os Estados da Amazônia por poder diversificar o sistema de produção e a renda das comunidades extrativistas (SOUZA \& TEZZA, 2000).

Assim como para a maioria das palmeiras, o murmuru é multiplicado a partir das sementes. A inconveniência deste tipo de propagação é que além da demora e do lento crescimento, plantas originadas deste processo apresentam alta variabilidade por tratar-se de um tipo gâmico de multiplicação. Por esse motivo, a adequação de técnicas para a propagação vegetativa é sem dúvida, um importante passo para a domesticação e exploração racional deste tipo de palmeira.

\footnotetext{
${ }^{1}$ Dr., Embrapa - Centro de Pesquisa Agroflorestal do Acre - Cx. P. 321 - 69908-970 - Rio Branco, AC - jonny@cpafac.embrapa.br

${ }^{2}$ Bolsista PIBIC/CNPq, Laboratório de Cultura de Tecidos Vegetais - Embrapa Acre - Cx. P. 321 - 69908-970 - Rio Branco, AC.

${ }^{3}$ Mestrando do Curso de Fitotecnia - Universidade Federal de Lavras/UFLA - Cx. P. 3037 - 37.200-000 - Lavras, MG.
} 
O cultivo de embriões in vitro constitui uma técnica promissora para avançar nos conhecimentos de determinadas espécies uma vez que a partir dela é possível reproduzir e estudar o desenvolvimento embrionário, a quebra da dormência e a produção de plântulas (COLLINS \& GROSSER, 1984; HU \& FERREIRA, 1998). Além disso, a cultura de embriões em palmeiras que normalmente apresentem lento processo de germinação, pode ser de grande utilidade para a obtenção de plantas em menor espaço de tempo (PINHEIRO, 1986). Acrescenta-se a isso o fato de que tecidos embrionários são excelentes explantes para serem usados em estudos, visando a propagação clonal in vitro em virtude de sua natureza juvenil e alto potencial regenerativo (PIERIK, 1990). Entretanto, um importante aspecto da cultura de embriões é definir um meio de cultura que possa sustentar o seu crescimento e desenvolvimento (HU \& FERREIRA, 1998). Com isso, tem-se buscado alternativas quanto à composição dos meios nutritivos que se aproximem da composição do endosperma ou do saco embrionário e possibilitem o desenvolvimento dos embriões, independentemente do estádio em que se encontram (ANDREOLI, 1986). O meio de cultura adequado, tanto para propagação quanto para a cultura de embriões, deve ser adaptado para cada espécie. Embora diferentes meios sejam capazes de manter os microcultivos de embriões, o mais freqüentemente utilizado é o MS (MURASHIGE \& SKOOG, 1962).

Em algumas espécies de plantas como os citros, há tendência de ocorrer a germinação de embriões imaturos originando plântulas fracas e mal formadas. Pelo fato de meios de cultura com elevada pressão osmótica suprimir a germinação precoce, alta concentração de sacarose tem sido utilizada para minimizar estes efeitos (PASQUAL \& PINTO, 1988). Segundo Grattapaglia \& Machado (1990), as plantas cultivadas in vitro requerem uma fonte de energia exógena, pois não dispõem de condições adequadas para a realização da fotossíntese. Diante disso, a sacarose tem sido a fonte de carbono mais utilizada, estando presente em meios de cultura em concentrações que variam de 20 a 40 g.L. - $^{-1}$ (FERREIRA et al., 2002). Portanto, variações na concentração deste carboidrato no meio de cultivo afetam as condições osmóticas e o metabolismo da planta in vitro, influenciando no crescimento e no metabolismo das culturas (KUMAR et al., 1984; OZAIAS-AKINS \& VASIL, 1982).

Segundo Hu \& Ferreira (1990), culturas de embriões de Datura nos estádios iniciais de desenvolvimento necessitam de concentração elevada de sacarose $(8 \%$ a $12 \%$ ), a qual é gradativamente reduzida à medida que os embriões atingem a maturidade. Ainda segundo estes autores, embriões excisados no estádio maduro ou próximo a este são quase autotróficos e, em geral, dependendo da espécie, não há necessidade de suplementação de fonte de energia.

Tendo em vista a necessidade de informações técnico-científicas sobre o murmuru, bem como pelo fato de que suas sementes utilizadas como material propagativo demandarem de seis meses a um ano para germinarem e as mudas apresentam lento crescimento (SOUSA et al., 2004), faz-se necessária a busca por técnicas alternativas que otimizem o sistema produtivo e ainda garantam a perpetuação da espécie.

Considerando os aspectos mencionados e o restrito conhecimento científico sobre a espécie Astrocaryum ulei, com este trabalho objetivou-se estudar a germinação in vitro de embriões zigóticos sob diferentes estádios fisiológicos de desenvolvimento e concentrações de sacarose no meio de cultura.

\section{MATERIAL E MÉTODOS}

O trabalho foi realizado no Laboratório de Cultura de Tecidos Vegetais, pertencente à Embrapa - Centro de Pesquisa Agroflorestal do Acre, em Rio Branco, AC. Os frutos utilizados para a retirada dos embriões foram obtidos a partir de plantas matrizes provenientes da área experimental da Embrapa Acre.

Frutos de murmuru (Astrocaryum ulei Mart.) foram coletados da planta-mãe quando se apresentavam sob dois estágios de desenvolvimento: maduros e imaturos. Frutos no estágio maduro apresentavam o epicarpo (casca) com coloração externa marrom-escura, mesocarpo (polpa) esverdeado, semente de coloração marrom-intensa bastante resistente e endosperma bem desenvolvido. Os frutos imaturos caracterizavam-se pela coloração externa marrom-clara do epicarpo, mesocarpo verde-claro, semente esbranquiçada pouco resistente e endosperma pouco consistente e não completamente desenvolvido (Figura 1).

Após a quebra da semente e extração dos embriões zigóticos com o auxílio de pinça e bisturi foi realizada a desinfestação dos mesmos. Em câmara de fluxo laminar os embriões foram imersos em álcool $70 \%$ por 30 segundos e solução de hipoclorito de sódio $1 \%$ por 10 minutos, sendo em seguida lavados três vezes em água destilada e autoclavada. 


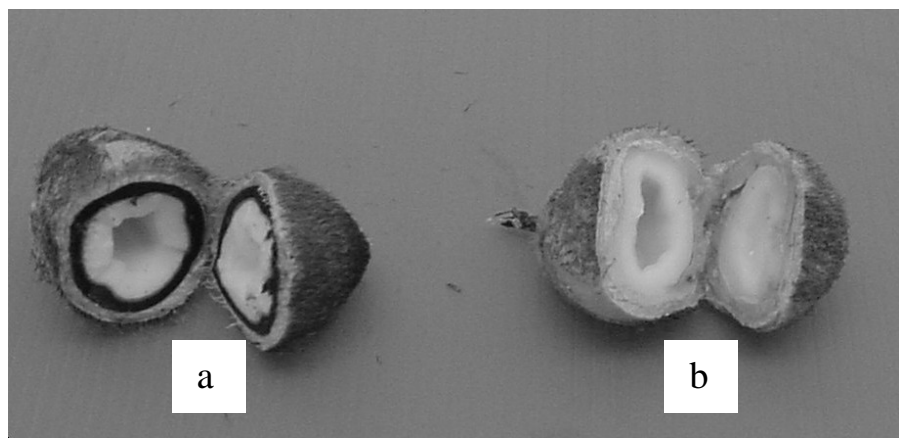

FIGURA 1 - Estágio de desenvolvimento maturo (a) e imaturo (b) dos frutos de murmuru usados para a extração dos embriões zigóticos visando o cultivo in vitro.

Uma vez desinfestados, os embriões foram cultivados em frascos de $250 \mathrm{~mL}$ contendo $30 \mathrm{~mL}$ de meio de cultura MS na concentração de $75 \%$ dos sais (macro e micronutrientes), suplementado com $2,5 \mathrm{mg} . \mathrm{L}^{-1}$ de ácido giberélico $\left(\mathrm{AG}_{3}\right), 100 \mathrm{mg} . \mathrm{L}^{-1}$ de inositol e solidificado com $5 \mathrm{~g} . \mathrm{L}^{-1}$ de ágar. $\mathrm{O} \mathrm{pH}$ do meio foi ajustado para $5,8 \pm 0,1$ antes da autoclavagem que foi realizada por 15 minutos a $121^{\circ} \mathrm{C}$ e $1,3 \mathrm{~atm}$. Os tratamentos consistiram da interação de concentrações de sacarose $\left(15,30\right.$ e 45 g.L $\left.\mathrm{L}^{-1}\right)$ combinadas com a idade fisiológica dos frutos (imaturos e maduros), num fatorial $2 \times 3 \mathrm{em}$ delineamento inteiramente casualizado com seis repetições e cinco embriões por parcela. Os resultados foram submetidos à análise de variância (ANAVA) e, na comparação entre médias, utilizouse o teste Tukey a 5\% de probabilidade.

As culturas foram mantidas em sala de crescimento com temperatura de $25 \pm 2^{\circ} \mathrm{C}$ em condições de escuro por 30 dias. Decorrido este período, foram avaliados a porcentagem de germinação dos embriões e altura das plântulas, sendo posteriormente transferido o experimento para condição luminosa de $30 \mathrm{mmol} \cdot \mathrm{m}^{-2} \cdot \mathrm{s}^{-1} \mathrm{e}$ fotoperíodo de 16 horas por até aproximadamente 120 dias para completo desenvolvimento.

\section{RESULTADOS E DISCUSSÃO}

A germinação dos embriões de murmuru começou a ser observada a partir da segunda semana de cultivo e, após 30 dias de cultivo, observou-se que a associação de sacarose à idade fisiológica dos embriões proporcionou diferenças significativas nas taxas de germinação do material cultivado in vitro (Tabela 1). De modo geral, embriões imaturos apresentaram maior taxa de germinação em meio suplementado com 30 g.L $\mathrm{L}^{-1}$ de sacarose. Nesta condição foi observado que $85,9 \%$ dos embriões germinaram, valor significativamente superior aos 50\% obtidos na concentração de $45 \mathrm{~g} . \mathrm{L}^{-1}$. Para os embriões obtidos de frutos maduros, 15 g. $\mathrm{L}^{-1}$ de sacarose no meio foi suficiente para que se alcançasse os melhores índices de germinação. Estes resultados confirmam a hipótese de que dependendo da espécie e do estágio de desenvolvimento dos embriões, a presença de carboidratos no meio de cultura pode ser em concentrações mínimas ou até dispensável em razão de embriões de muitas espécies utilizarem a energia necessária para a germinação in vitro a partir das próprias reservas do embrião (GARCÍA et al., 2002).

Ribeiro et al. (1998), utilizando concentrações de sacarose entre 0 e 60 g.L. - $^{-1}$ observaram elevado índice de sobrevivência de embriões de Laranja-pêra em todos os níveis de sacarose utilizados, evidenciando ser a sacarose dispensável para o início do desenvolvimento dos embriões cultivados in vitro para esta espécie. Conforme $\mathrm{Hu} \&$ Ferreira (1998), embriões excisados no estádio maduro ou próximo a este são quase autotróficos e, em geral, dependendo da espécie, não há necessidade de suplementação de fonte de energia. No entanto, embriões mais jovens normalmente necessitam de concentrações mais elevadas de carboidratos no meio de cultura para sustentar sua germinação (BRIDGEN, 1994). Ferreira et al. (2002), obtiveram melhores resultados com a utilização de $3 \%$ de sacarose no desenvolvimento de eixos embrionários de cupuaçu, em concordância com Duhem \& Le Mercier (1989), Janick \& Whipkey (1985), Kononowicz \& Janick (1984) e Söndhal et al. (1993) em trabalhos realizados com Theobroma cacao.

Na média, houve maior germinação nos embriões obtidos de frutos imaturos (Tabela 1), fato confirmado pela significância observada nas médias de germinação 
dos embriões oriundos de frutos imaturos e maduros (68,8\% e 40,6\%, respectivamente). Quanto à média de sacarose não foi observada diferença significativa entre as concentrações testadas, levando a inferir que o estágio fisiológico dos frutos influenciam a taxa de germinação dos embriões zigóticos de $A$. ulei sob estas condições de cultivo.

$\mathrm{Na}$ média, os melhores resultados para altura de plântulas foram observados quando se utilizou embriões provenientes de frutos maduros (Tabela 2). Para esses embriões a suplementação do meio com 30 e 45 g.L $L^{-1}$ de sacarose proporcionou valores de altura de plântulas estatisticamente superiores à concentração de 15 g.L.- . Resultados semelhantes foram obtidos em feijoeiro por Gallo (1994), em que a sacarose adicionada ao meio de cultura em concentrações crescentes favoreceu o crescimento e o desenvolvimento dos embriões.

Entre os embriões oriundos de frutos imaturos não foram observadas diferenças significativas entre os níveis de sacarose testados. No entanto, na comparação entre os diferentes estágios de desenvolvimento dos embriões, observou-se que com exceção da concentração de 15 g.L${ }^{1}$, nas demais concentrações de sacarose embriões oriundos de frutos maduros apresentaram maior crescimento, indicando que embriões mais desenvolvidos suportam melhor o crescimento in vitro, possivelmente em razão do estágio mais avançado de diferenciação dos tecidos. Além disso, os dados confirmam os resultados obtidos por outros autores e suportam a idéia de que a germinação de embriões in vitro pode até acontecer em meios de cultura com baixa concentração de carboidratos, mas não para o posterior crescimento das plântulas (GARCÍA et al., 2002). Ribeiro et al. (1998), concluíram que embriões imaturos de laranja-pêra em diferentes idades apresentaram melhor desenvolvimento no meio de cultura de MS com $75 \%$ da sua fórmula original e 45, 0 a 60,0 g.L $\mathrm{L}^{-1}$ de sacarose.

$\mathrm{O}$ aspecto das plântulas de murmuru formadas a partir da germinação dos embriões zigóticos pode ser observado na Figura 2.

TABELA 1 - Influência do estágio de desenvolvimento da semente e da concentração de sacarose no percentual de germinação in vitro de embriões zigóticos de murmuru (Astrocaryum ulei). Embrapa, Rio Branco, 2004.

\begin{tabular}{cccc}
\hline \multirow{2}{*}{ Sacarose (g.L $\left.\mathbf{L}^{\mathbf{- 1}}\right)$} & \multicolumn{2}{c}{ \% de germinação } & \multirow{2}{*}{ Média } \\
\cline { 2 - 3 } & Semente imatura & Semente madura & $61,9 \mathrm{a}$ \\
30 & $67,4 \mathrm{abA}$ & $56,5 \mathrm{aA}$ & $55,4 \mathrm{a}$ \\
45 & $85,9 \mathrm{aA}$ & $25,0 \mathrm{bB}$ & $45,6 \mathrm{a}$ \\
Média & $50,0 \mathrm{bA}$ & $41,3 \mathrm{abA}$ & \\
\hline
\end{tabular}

Médias seguidas de mesma letra minúscula, nas colunas e maiúscula nas linhas, dentro de um mesmo fator, não diferem estatisticamente entre si pelo teste Tukey a 5\% de probabilidade.

TABELA 2 - Altura ( $\mathrm{mm}$ ) de plântulas de murmuru originadas de embriões zigóticos germinados in vitro em razão do estágio de desenvolvimento da semente e concentrações de sacarose no meio de cultura. Embrapa, Rio Branco, 2004.

\begin{tabular}{cccc}
\hline \multirow{2}{*}{ Sacarose (g.L $\left.\mathbf{L}^{\mathbf{1}}\right)$} & \multicolumn{2}{c}{ Altura das plântulas $(\mathbf{m m})$} & \multirow{2}{*}{ Média } \\
\cline { 2 - 3 } & Semente imatura & Semente madura & $6,1 \mathrm{~b}$ \\
15 & $6,5 \mathrm{aA}$ & $5,7 \mathrm{bA}$ & $9,7 \mathrm{a}$ \\
30 & $7,0 \mathrm{aB}$ & $12,5 \mathrm{aA}$ & $10,0 \mathrm{a}$ \\
Média & $6,9 \mathrm{aB}$ & $13,1 \mathrm{aA}$ & \\
\hline
\end{tabular}

Médias seguidas de mesma letra minúscula, nas colunas e maiúscula nas linhas, dentro de um mesmo fator, não diferem estatisticamente entre si pelo teste Tukey a $5 \%$ de probabilidade.

Ciênc. agrotec., Lavras, v. 30, n. 2, p. 251-256, mar./abr., 2006 

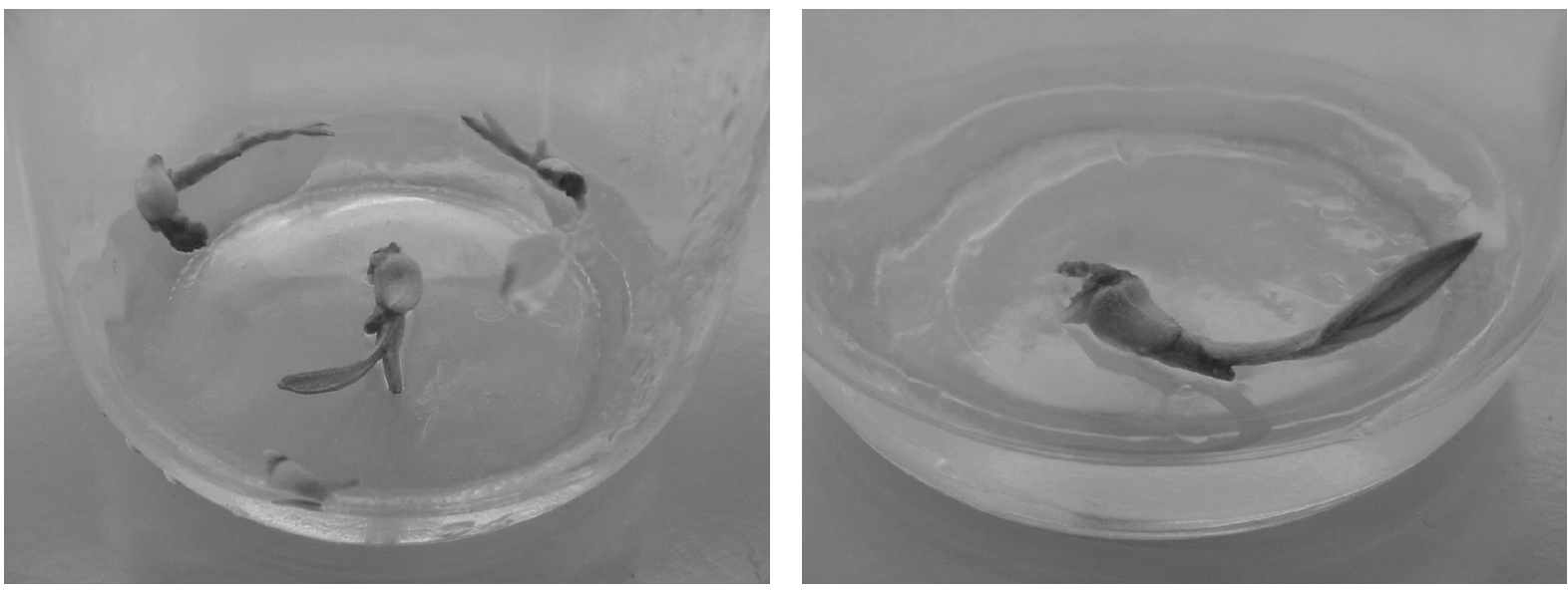

FIGURA 2 - Aspecto de plântulas de murmuru formadas a partir da germinação in vitro de embriões zigóticos, após dois a três meses de cultivo.

\section{CONCLUSÕES}

a) Embriões zigóticos provenientes de frutos imaturos de murmuru apresentam melhores índices de germinação in vitro quando comparado a embriões oriundos de sementes maduras;

b) Embriões em estádio maduro necessitam de concentrações não superiores a 15 g.L. $\mathrm{L}^{-1}$ de sacarose no meio de cultura para as melhores taxas de germinação, apesar de necessitarem de concentrações maiores para sustentar o posterior crescimento das plântulas;

c) Sob condições in vitro, embriões zigóticos de murmuru germinam a partir da segunda semana de cultivo.

\section{AGRADECIMENTOS}

Aos pesquisadores Dr. João Alencar de Sousa pelo fornecimento das sementes e Valter Barbosa Magalhães pelo auxílio na obtenção dos embriões. Ao CNPq pela concessão das bolsas PIBIC.

\section{REFERÊNCIA BIBLIOGRÁFICA}

ANDREOLI, C. Cultura de embriões. In: SIMPÓSIO DE CULTURA DE TECIDOS VEGETAIS, 1., 1985, Brasília, DF. Anais... Brasília, DF: ABCTP/EMBRAPA, 1986. p. 25-28.

BRIDGEN, M. P. A review of plant embryo culture. HortScience, Alexandria, v. 29, n. 11, p. 1243-1246, 1994.
COLLINS, G. B.; GROSSER, J. W. Culture of embryos. In: VASIL, I. K. (Ed.). Cell culture and somatic cell genetics of plants. New York: Academic, 1984. v. 1, p. 241-257.

DUHEM, K.; LE MERCIER, N. Données nouvelles sur l'induction et le développement d'embryons somatiques chez Theobroma cacao L. Café Cacao Thé, Paris, v. 33, n. 1, p. 9-14, 1989.

FERREIRA, M. G. R.; CÁRDENAS, F. H. N.; CARVALHO, C. H. S. C.; CARNEIRO, A. A.; DANTAS FILHO, C. F. Resposta de eixos embrionários de cupuaçu (Theobroma grandiflorum Schum.) à concentração de sais, doses de sacarose e renovação do meio de cultivo. Revista Brasileira de Fruticultura, Jaboticabal, v. 24, n. 1, p. 246248, 2002.

GALLO, L. A. Atividade da enzima sintetase de glutamina em embriões de feijão cultivados in vitro. 1994. 124 f. Tese (Doutorado) - Escola Superior de Agricultura "Luiz de Queiroz”, Piracicaba, 1994.

GARCÍA, J. L.; TRONCOSO, J.; SARMIENTO, R.; TRONCOSO, A. Influence of carbon source and concentration on the in vitro development of olive zygotic embryos and explants raised from them. Plant Cell, Tissue and Organ Culture, Dordrecht, v. 69, p. 95-100, 2002. 
GRATTAPAGLIA, D.; MACHADO, M. A. Micropropagação. In: TORRES, A. C.; CALDAS, L. S. Técnicas e aplicações da cultura de tecidos de plantas. Brasília, DF: ABCTP/EMBRAPA-CNPH, 1990. p. 99-169.

HU, C. Y.; FERREIRA, A. G. Cultura de embriões. In: TORRES, A. C.; CALDAS, L. S.; BUSO, J. A. (Eds.). Cultura de tecidos e transformação genética de plantas. Brasília, DF: EMBRAPA-SPI/EMBRAPA-CNPH, 1998. v. 1, p. 371393.

JANICK, J.; WHIPKEY, A. Axillary proliferation of shoots from cotyledonary nodal tissue of cacao. Revista Theobroma, Ilhéus, n. 15, p. 125-131, 1985.

KONONOWICZ, A. K.; JANICK, J. In vitro development of zygotic embryos of Theobroma cacao. Journal of the American Society of Horticultural Science, Alexandria, v. 109, n. 2, p. 266-269, 1984.

KUMAR, A.; BENDER, L.; NEUMANN, K. H. Growth regulation, plastid differentiation and the development of a photosynthetic system in cultured carrot root explants as influenced by exogenous sucrose and various phytohormones. Plant Cell, Tissue and Organ Tissue Culture, Dordrecht, v. 4, p. 11-28, 1984.

MURASHIGE, T.; SKOOG, F. A revised medium for rapid growth and bioassays with tobacco tissue cultures. Physiologia Plantarum, Copenhagen, v. 15, p. 473-497, 1962.

OZAIAS-AKINS, P.; VASIL, I. K. Plant regeneration from cultured immature embryos and inflorescences of Triticum aestivum L.: evidence for somatic embryogenesis. Protoplasma, New York, v. 110, p. 95-105, 1982.

PASQUAL, M.; PINTO, J. E. B. P. Cultura de embriões. Notícias da Associação Brasileira de Cultura de Tecidos de Plantas, Brasília, v. 9, p. 2-12, ago. 1988.

PIERIK, R. L. M. Cultivo in vitro de las plantas superiores. 3. ed. Madrid: Mundi-Prensa, 1990. 326 p.

PINHEIRO, C. M. B. Germinação de sementes de palmeiras: revisão bibliográfica. Teresina: EMBRAPAUEPAE, 1986. 102 p.

RIBEIRO, V. G.; PASQUAL, M.; RAMOS, J. D.; VICHIATO, M.; SANÁBIO, D. Cultivo in vitro de embriões de Laranja 'Pêra': concentrações do meio MS e sacarose. Ciência e Agrotecnologia, Lavras, v. 22, n. 4, p. 429-434, 1998.

SÖNDAHL, M. R.; LIU, S.; BELLATO, C.; BRAGIN, A. Cacao somatic embryogenesis. Acta Horticulturae, Wageningen, n. 336, p. 245-248, 1993.

SOUZA, A. D.; TEZZA, J. B. Apoio ao manejo e comercialização da palmeira murmuru (Astrocaryum spp.) no Vale do Alto Juruá. Rio Branco, AC: SEPRO/SEFE, 2000. 19 p. (Relatório).

SOUSA, J. A. de; RAPOUSO, A.; SOUZA, M. de M. M.; MIRANDA, E. M. de; SILVA, J. M. M. da; MAGALHÃES, V. B. Manejo de Murmuru (Astrocaryum spp.) para produção de frutos. Rio Branco, AC: Secretaria de Extrativismo e Produção Familiar, 2004. 30 p. (Documento técnico, 1).

Ciênc. agrotec., Lavras, v. 30, n. 2, p. 251-256, mar./abr., 2006 